\title{
Law Enforcement on Consumer Protection In Electronic Sale And Purchase Agreements
}

\author{
Adhyaksono Bagus Pratomo \\ \{tomy.adhyaksono@gmail.com\} \\ Doctor of Law, Universitas Jayabaya, Jakarta, Indonesia
}

\begin{abstract}
The enforcement of consumer protection laws is compulsory, because as the benchmark of national development, law is expected to increase community's trust in the government in carrying out comprehensive reforms in various aspects. Electronic agreements on electronic media between sellers and buyers should be able to protect their rights. It is necessary to protect all parties involved in virtual business where sellers (business actor) and buyers (consumer) do not meet directly from default and a method must be designed to resolve disputes regarding virtual transactions. This normative juridical research analyzed secondary data consisting of primary legal materials, secondary legal materials and tertiary legal materials. The analysis was carried out using qualitative juridical analysis which results showed that the settlement of electronic agreement disputes can be carried out by the parties through civil lawsuits (litigation) and non-litigation or Alternative Dispute Resolution (APS) as mentioned in Article 39 paragraph (2) of the ITE Law, Article 65 Paragraph (5) Law No. 7/2014 and Article 72 Law No. 80/2019. Nonlitigation dispute resolution is often taken by consumers by filing complaints to NonGovernmental Organization/YLK, Director General of Legal Protection and Trade Order Ministry of Religion. In practice, dispute resolution between business actors/Marketplace and consumers in electronic trading is more frequently resolved through BPSK by means of APS.
\end{abstract}

Keywords: Consumer Protection; Virtual Sales and Purchase; Default

\section{Introduction}

An agreement or contract has not required face to face meeting anymore. With the advent of technological information, many agreements, especially in a business transaction, tend to be conducted online. It is unsurprising since, without face-to-face meeting, the parties involved can maximalise time efficiency and place flexibility. In Indonesia, it has been a new trend; more and more people are signing an agreement, including sale and purchase agreements, online. That sort of trading activity has become an integral part of national and international trading or business ventures. Indonesia itself has made its legal instruments with Law No. 19 of 2016 and amendments to Law No.11 of 2008 concerning Electronic Information and Transactions.

Although this may bring many advantages, this new trend also cast some legal doubts. Firstly, this definition of agreement is a shift from the definition of agreement in Article 1320 of the Indonesia Civil Code, which specifies the agreement's validity through a face-to-face 
meeting. With this new meaning of the agreement, anyone, including underage, can sign an agreement despite its legal problems. Secondly, this agreement often does not benefit the customers. Behind the online convenience and practicality, online shopping may imperil consumer rights. Many cases are associated with product defects, dishonest information in webvertising, or late delivery of goods. Against the background, the sale and purchase agreement through electronic transactions needs to be assessed, especially its legal protection for consumers. An electronic agreement should protect the parties involved's rights, both the seller and the buyer, especially the customers, from harms and ill-intention.

\section{Research Methods}

This study applied a normative juridical research method, a study focused on examining theories, concepts, legal principles, and regulations of the main law, which, in this case, is focused on the Constitutional Court Decision in the 2020 Election. This research is qualitative and uses a deductive thinking method to conclude generalization, which ten is used for something specific to solve the problem.

\section{Results and Discussion}

The principle of freedom to contract allows the parties who agree to form an agreement to determine the form and content of an agreement by themselves. Thus, the parties who agree can regulate their legal relationship. As in conventional trade, e-commerce creates an engagement between the parties to achieve achievement. The implication of the engagement is the emergence of rights and obligations that must be fulfilled by the parties involved. In Indonesian law, this agreement is stated in Law Number 7 of 2014:

"Business actors in electronic commerce are obliged to register and comply with the technical provisions of the relevant agencies. Every business actor must have and declare business ethics (business conduct or code of practices). Business actors are prohibited from requiring consumers to pay for products shipped without prior agreement (inertia selling). Electronic information or documents can be used as evidence as they have the same legal force as an authentic deed."

Furthermore, considering that consumer protection law is essential amidst technological development because, for example, buying and selling online process enables consumers' data such as ID card or bank account number, to be stolen as proof of identity, Indonesia has ratified Article 2 of Law Number 8 of 1999 concerning Consumer Protection that says:

Consumer protection is based on benefits, fairness, balance, security, and consumer safety, as well as legal certainty. The protection of these personal identifications from the sellers or marketplaces are imperative to prevent anxiety during the transaction. This is necessary so that consumer protection principles are well fulfilled while simultaneously implementing rights and obligations of consumers and business actors. That is, by ratifying the law, Indonesia tried to support all stakeholders involved in the traffic of transaction.

However, the electronic system still contains some problems inspected from the civil law system perspective. For example, based on data from the Indonesian Consumers Foundation (Yayasan Lembaga Konsumen Indonesia-YLKI) in 2014, online shopping complaints were not among the top 10 consumer complaints, but in 2015 complaints about e-commerce increased 
to the third position. In 2015 there were 77 complaints cases against e-commerce with details of $20 \%$ ( 16 cases) concerning the withdrawal of the already deposited (refund) costs, $16 \%$ (13 cases) concerning incongruent information about the details of goods and their actual appearances, and $15 \%$ (12 cases) concerning the long delivery process to the consumer from online businesses. Indeed, in 2016 there were 642 complaints to YLKI, in which online stores dominated 101 complaints, and in 2017 during National Online Shopping Day (Hari Belanja Online Nasional-Harbolnas), of 71 complaints, $46 \%$ of it is online shopping complaints. In 2019 the Financial Services Authority (Otoritas Jasa Keuangan-OJK) recorded 19,000 online shopping complaints, and the majority of cases were undelivered cases.

The incidents above are necessary to be immediately inspected and intervened by the government, considering that various legal provisions and regulations have been issued, namely the ITE Law, Government Regulation 82 of 2012, Law number 7 of 2014 and Government Regulation 80 of 2019. Yet, in reality, it seems that the realization is slow-moving, or it seems that the public has not yet understood it. In fact, because the concerns intersect between two executive bodies: The Ministry of Communication and Information Technology of the Republic of Indonesia (Kementerian Komunikasi dan Informatika-Kemenkominfo) and the Ministry of Trade (Kementerian Perdagangan-Kemendag), there is an impression that each ministry mentioned waits for whom the complaints are addressed before proceeding to a solution.

Of the five principles of consumer protection, the researcher found that four principles are not fulfilled. This makes that consumers in a weak position in online/ electronic sale and purchase agreements. In other words, although the regulation already exists, the violations are still ongoing. This is likened to the incongruency between das sollen and das sein in legal terms.

According to the consumer protection law theory, disputes in business must be resolved immediately to prevent the existing businesses from not suffering major losses and for the sake of upholding the principles of justice and the principles of legal protection. In that case, two lawful measures can be taken into account to solve it:

a. Litigation (through court channels).

b. Non-Litigation (opting-out court process)

Dispute Resolution Through Court

The use of the Alternative Dispute Resolution Agreement (Alternatif Penyelesaian Sengketa-APS) is regulated in Law number 30 of 1999. Business actors can use several models on dispute settlement alternative, including negotiation, consultation, binding opinions, mediation, conciliation, adjudication, and arbitration. Even in its development, civil dispute resolution institutions were born as a distinctive settlement or a process carried out by the parties themselves with the assistance of a neutral mediator. The adaptation process of the agreement between the parties as outlined in the sale and purchase agreement can be performed on the internet, and the purpose is to make the parties jointly change the contents of the agreement. As a result, an act of a party originally considered against the law eventually is no longer considered against the law.

Online Dispute Resolution (ODR) has occurred in several developed countries, such as the United States and Europe. In Indonesian, PDS or ODR has not been implemented even though it is possible because all electronic data and electronic signatures can be used as legal evidence according to the ITE Law in adjacent to article 79 paragraph 2 of The Law number 7 of 2014, article 72 paragraph (1) Government Regulation number 80 of 2019 and other regulations. Hopefully, implementing ODR/ SD in dispute resolution within the realm of an online transaction can increase public trust with the availability of a fast dispute resolution model and a legal breakthrough to protect parties, both business actors and consumers, in seeking justice. 


\section{Conclusion}

Legal protection for consumers in e-commerce transactions needs to be handled optimally, given the rampant complaints made by consumers who have been harmed by business actors. Following the enactment of Government Regulation number 80 of 2019 concerning PMSE, which is the mandate of Article 66 of Law Number 7 of 2014 concerning PSE, the related government agency in the form of Non-Departmental Higher Institutions (under the direct auspice of the President), which have great power, is necessary to help solve consumer electronics problems quickly. Customers often settle the disputes through non-litigation channels by filing a complaint first through the Non-Governmental Organization, DirectorGeneral of Legal Protection and Commercial Order of the Ministry of Religion, and in practice, dispute resolution between business actors, marketplace, and consumers in electronic trading, is preferred to be resolved through BPSK and APS.

\section{References}

[1] Wulandari, Y. S. (2018). Perlindungan Hukum bagi Konsumen terhadap Transaksi Jual Beli ECommerce. AJUDIKASI: Jurnal Ilmu Hukum, 2(2).

[2] Anggraeni, R. D., \& Rizal, A. H. (2019). Pelaksanaan Perjanjian Jual Beli Melalui Internet (ECommerce) Ditinjau Dari Aspek Hukum Perdataan. SALAM: Jurnal Sosial dan Budaya Syar-i, 6(3), 223-238

[3] Mukhidin, S. (2010). Asas Kebebasan Berkontrak Dalam Kaitannya Dengan Perjanjian Baku. Cermin, (047).

[4] Ranto, R. (2019). Tinjauan Yuridis Perlindungan Hukum Terhadap Konsumen Dalam Transaksi Jual Beli Melalui Media Elektronik. Jurnal Ilmu Hukum: ALETHEA, 2(2), 145-164 